УДК 550.53

\title{
КРИТЕРИИ ПЕРЕОЦЕНКИ ПЕРСПЕКТИВ НЕФТЕГАЗОНОСНОСТИ КОЛЛЕКТОРНЫХ ЗОН ФУНДАМЕНТА ЮГО-ВОСТОКА ЗАПАДНОЙ СИБИРИ
}

\author{
Белозёров Владимир Борисович1, \\ BelozerovVB@hw.tpu.ru
}

Силкин Геннадий Евгеньевич2, gsilkin@geoprime.ru

\author{
1 Национальный исследовательский Томский политехнический университет, \\ Россия, 634050, г. Томск, пр. Ленина, 30. \\ 2 Филиал ООО «ГеоПрайм»-«Томская геофизическая компания», \\ Россия, 634029, г. Томск, пр. Фрунзе, 39.
}

\begin{abstract}
Актуальность. Образования палеозоя Западной Сибири являются основным объектом дальнейшего наращивания углеводородного потенциала рассматриваемой территории. Сложность геологического строения пород фундамента, неудовлетворительное качество бурения, крепления и испытания скважин обусловили низкую эфффективность нефтепоисковых работ в отложениях палеозоя, где все выявленные месторождения и залежи углеводородов открыты попутно с проведением геологоразведочных работ на объекты осадочного чехла. Одно из перспективных направлений повышения эффрективности поисковых работ в породах фрундамента связано с анализом особенностей бурения и результатов испытания ранее пробуренных скважин, где можно выделить геологический и технологический факторы. Геологический фактор рассматривает результаты бурения и испытания скважины с позиции блоковой, складчатой, слоистой модели строения трещиновато-поровокавернозной коллекторной зоны, выделяемой в составе палеозойского комплекса. Анализируемая складчато-слоистая модель позволяет оценить возможность изменения объёма сжимаемого флюида (нефрть, газ) в процессе бурения и испытания скважины. При бурении, в результате повышенного давления на забое скважины относительно пластового в продуктивном пласте, обладающем аномально высокими фрильтрационно-емкостными свойствами, происходит уменьшение объёма углеводородного фрлюида, что приводит к поглощению промывочной жидкости, иногда до полной потери циркуляции. Этот эфрфект может наблюдаться при бурении скважины как в контуре залежи, так и в водоносной зоне в непосредственной близости от неё. При испьтании скважины и снижении давления в процессе её освоения происходит расширение (релаксация) ранее сжатых объёмов углеводородного фрлюида. В случае бурения скважины в водонефтяной зоне наблюдаются сменяющиеся водонефртяные и неффтеводяные притоки, а при расположении скважины в водоносной части залежи отмечается самопроизвольный излив или высокие дебиты на незначительных динамических уровнях высокоминерализованной пластовой воды с повышенными значениями газового фрактора относительно значений предельного насьщения. Технологический фактор оценивает качество цементирования эксплуатационной колоны, влияющий на конечные результаты испытания и, как следствие, на оценку перспектив нефртегазоносности анализируемого разреза скважины. Проведённая систематизация результатов бурения и испытания позволяет определить критерии для оценки перспектив нефтегазоносности изучаемых скважин и площадей с целью возобновления поисковых работ для открытия залежей углеводородов в породах доюрского комплекса.

Цель исследования заключается в анализе результатов бурения и испытания скважин, проводимых в породах фундамента юго-восточной части Западно-Сибирской плиты для выделения нефтеперспективных участков и возобновления поисковых работ на ранее изученных площадях.

Объектом исследования являются отложения палеозойского фундамента юго-восточной части Западно-Сибирской плиты, которые представлены породами различного вещественного состава, включая карбонатные разности.

Выполнен анализ результатов бурения и испытания скважин, проводимых в палеозойском комплексе, определены критерии полученных данных для возможного возобновления нефртепоисковых работ на площадях, ранее изученных глубоким бурением.
\end{abstract}

\section{Ключевые слова:}

Доюрский осадочный комплекс, породы фундамента, результаты испытания доюрского осадочного комплекса, поглощение бурового раствора, переливы пластовых вод.

\section{Введение}

В условиях значительного сокращения подготовленных запасов углеводородного сырья по отложениям осадочного чехла все большее внимание недропользователей привлекает доюрский комплекс (ДЮК) палеозойского фундамента. Рассматриваемый комплекс в отличие от отложений платформенного чехла характеризуется существенно более сложным геологическим строением, что обусловлено:

- значительным проявлением блоковой тектоники в породах фундамента в сочетании с неоднократным выходом отложений на эрозионную поверх- ность, последующим их размывом и формированием кор выветривания;

- многообразием вещественного состава ДЮК - от интрузивных и вулканогенных эффузивных пород и их разностей до осадочных карбонатнотерригенных отложений и продуктов их метаморфизма и разрушения;

- низкой эффективностью сейсмических и других дистанционных методов исследований при картировании как внутренней структуры палеозоя, так и его эрозионно-тектонической поверхности;

- низким выносом керна, особенно в перспективных трещинных, кавернозных, кавернозно-трещинных 
интервалах разреза, не превышающим первых процентов от длины интервала отбора, а иногда и полным его отсутствием;

- сложностью выделения коллекторных зон (КЗ) скважинными геофизическими методами;

- осложнениями и высокой аварийностью в процессе бурения, в результате чего значительное число скважин ликвидировано без получения геологической информации;

- низким качеством цементирования (изоляции) затрубного пространства эксплуатационных колонн, особенно в потенциально продуктивных интервалах;

- высокой степенью неоднозначности результатов испытания объектов.

Следует отметить, что практически все залежи углеводородов в ДЮК были открыты «попутно» скважинами, основная задача которых состояла в поиске углеводородов (УВ) в отложениях осадочного чехла платформы. Образования фундамента при этом вскрывались в основном на глубины от нескольких метров до 50-70 м, в редких случаях более 100 м, вследствие чего в настоящее время наиболее хорошо изучена верхняя часть ДЮК, представленная проницаемыми толщами коры выветривания (пласт М) и кровлей палеозойских образований (пласт М1).

Планомерное изучение перспектив ДЮК было сосредоточено на уже открытых месторождениях и окружающих их территориях с привлечением комплексных исследований методами сейсморазведки, потенциальных полей, грави- и магниторазведки.

Глубина вскрытия пород фундамента параметрическим бурением на этих территориях достигала 1000-1500 м, что позволило получить определённые представления о перспективах нефтегазоносности его глубинных частей.

Анализ и систематизация накопленной информации позволяют сформировать критерии для переоценки полученных в результате бурения данных и определить скважины и участки, где необходимо возобновить поисковые работы с целю открытия залежей углеводородов в породах фундамента.

\section{Модели продуктивных объектов ДЮК}

Правильное понимание процесса бурения и испытания скважин в отложениях палеозоя во многом зависит от особенностей строения продуктивных коллекторов в ДЮК.

Рассматривая модель строения продуктивных резервуаров ДЮК необходимо отметить, что пространственное распределение залежей контролируется блоковой разнородностью образований палеозоя [1-6], а особенность испытания обусловлена различиями коллекторских свойств слоистой неоднородности складчатой системы фундамента [7-15].

Складчато-блоковая неоднородность подтверждается материалами сейсморазведки, где первичная обработка данных проведена по определённому графу [16], и результатами стратиграфического анализа керна глубоких скважин (рис. 1). По материалам про- странственно-ориентированного керна [17] и результатам стратиграфических исследований пород фундамента в пробуренных скважинах [18] в пределах Калиновой площади выделяется антиклинальная и синклинальная складки северо-западного простирания, осложнённые амплитудными тектоническими нарушениями (рис. 1, Б). При углах падения слоистости складки 20-44 градуса амплитуда смещения границы среднего и верхнего девона в сводовой и крыльевой частях складки в скважинах 25 и 16, расположенных на расстоянии 750 м, составляет 1040 м. При этом наиболее опушенным является свод антиклинальной складки (скв. 16) относительно её крыльевых частей (скв. 25). Складчато-блоковая модель хорошо интерпретируется и по данным сейсморазведки Арчинско-Урманской площади (рис. 1, А), где также отмечается вертикальное смещение разновозрастных блоков фундамента, представленных фрагментами антиклинальных и синклинальных складок.

Слоистая, фильтрационная неоднородность КЗ пород фундамента подтверждается результатами бурения горизонтальной скважины 1201 Арчинской площади, представленными в таблице, из которой следует, что складчатый комплекс продуктивного горизонта по данным механических параметров бурения характеризуется ярко выраженной слоистой, фильтрационно-емкостной неоднородностью. Это отражается в активном поглощении бурового раствора, высокой скорости бурения и «провала» инструмента в пределах выделяемых высокоёмких проницаемых прослоев карбонатного коллектора.

Таблица. Параметры бурения и газопоказания горизонтальной скважсины 1201 Арчинской площади

Table. Drilling parameters and gas indications of the horizontal well 1201, Archinskaya square

\begin{tabular}{|c|c|c|c|}
\hline $\begin{array}{l}\text { Интервал } \\
\text { Interval }\end{array}$ & $\begin{array}{l}\text { Газопоказания, \% } \\
\text { Gas indications, \% }\end{array}$ & $\begin{array}{c}\text { Скорость } \\
\text { бурения, м/ч } \\
\text { Drilling speed, } \\
\text { m/h }\end{array}$ & $\begin{array}{c}\text { Поглощение, } \\
\mathrm{m}^{3} / \mathrm{q} \\
\text { Absorption, } \\
\mathrm{m}^{3} / \mathrm{h}\end{array}$ \\
\hline $3725 \ldots 3729$ & $0,1 \ldots 0,4$ & $6-33$ & $\begin{array}{c}\text { Без выхода } \\
\text { циркуляции } \\
\text { Without circu- } \\
\text { lation outlet }\end{array}$ \\
\hline $3729 \ldots 3752$ & $0,1 \ldots .2,5$ & $5-15$ & $18-26$ \\
\hline $3752 \ldots 3766$ & до $49 /$ to 49 & $5-12$ & $15-18$ \\
\hline $3766 \ldots 3791$ & $0,5 \ldots \ldots 1,6$ & $4-8$ & $14-16$ \\
\hline $3791 \ldots 3815$ & до $32 /$ to 32 & $4-8$ & $6-8$ \\
\hline $3815 \ldots 3861$ & $1,1 \ldots 1,6$ & - & $6-10$ \\
\hline $3861 \ldots 3880$ & $0,2 \ldots .16,2$ & $\begin{array}{c}\text { 8-95 (провал } \\
\text { инструмента) } \\
\text { (fall drilling } \\
\text { tools) }\end{array}$ & $\begin{array}{c}\text { Полная поте- } \\
\text { ря циркуля- } \\
\text { ции } \\
\text { Complete loss } \\
\text { of circulation }\end{array}$ \\
\hline $3880 \ldots 3890$ & $1,5 \ldots .2,1$ & $6-8$ & $10-18$ \\
\hline
\end{tabular}

Присутствие в строении слоисто-складчатого фундамента, представленного карбонатными породами, интервалов трещинно-кавернозно-карстового коллектора оказывает существенное влияние на особенности проводки скважины и результаты её испытания. 


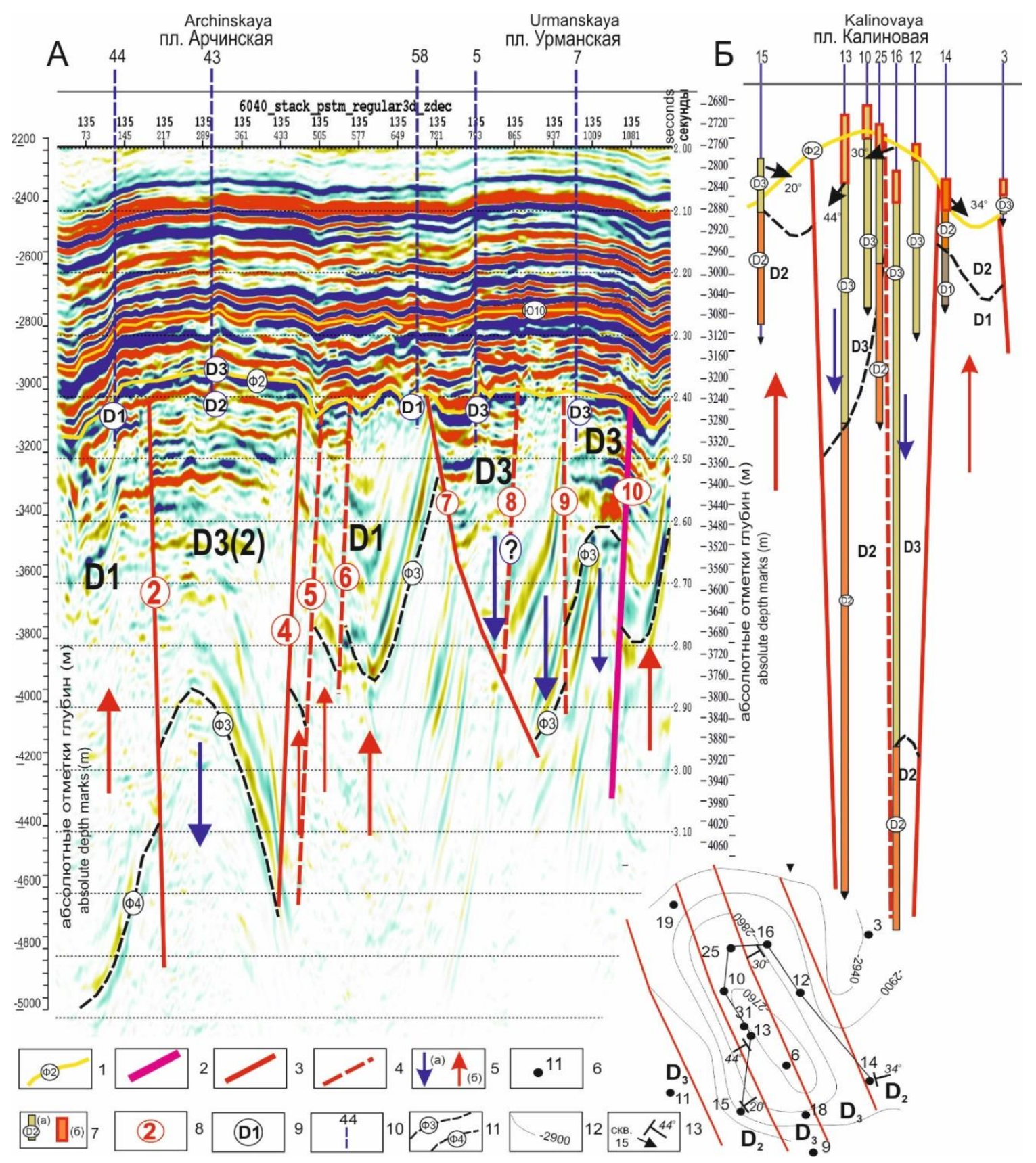

Pис. 1. Складчато-блоковое строение фундамента Урмано-Арчинской и Калиновой площадей по данным сейсмического профиля (А) и результатам глубокого бурения (Б): 1 - отражающий сейсмический горизонт кровли фундамента (Ф2); 2 - региональные тектонические нарушения в фундаменте (по В.С. Суркову); 3 - тектонические нарушения; разделяющие различные стратиграфические блоки; 4 - тектонические нарушения в пределах однородных стратиграфических блоков; 5 - погружение (а) и поднятие (б) крупных блоков фундамента; 6 - скважина, её номер; 7 - определение возраста пород фундамента по разрезу скважины (a) и интерваль коры выветривания (б); 8 - номер тектонического нарушения, выделенного по сейсморазвдке; 9 - возраст пород фундамента по данным пробуренных скважин; 10 - скважины, вынесенные на линию сейсмического профиля; 11 - прогнозное распределение сейсмических грании палеозойского фундамента; 12 - сейсмоизогипсы отражающего горизонта Ф2 (кровля пород фундамента); 13 - азимут и угол падения слоистости в отложениях палеозоя по данным ориентированного керна

Fig. 1. Fold-block structure of the Urmano-Archinskaya and Kalinovaya basement areas according to seismic profile data $(A)$ and results of deep drilling $(B): 1$ - reflective seismic horizon of the basement roof $(\Phi 2) ; 2$ - regional tectonic faults in the basement (according to $V$. Surikov); 3 - tectonic faults, separating different stratigraphic blocks; 4 - tectonic faults within homogeneous stratigraphic blocks; 5 - immersion (a) and uplift $(b)$ of large blocks of the foundation; 6 -well, its number; 7 - determination of the basement rocks age along the well section (a) and intervals of the weathering crust (b); 8 - number of tectonic fault identified by seismic survey; 9 - basement rocks age according to drilled wells; 10 - wells, which placed on the seismic line; 11 - predicted distribution of seismic boundaries of the Paleozoic basement; 12 - seismic isohypses of the reflecting horizon $\Phi 2$ (top of the basement rocks); 13 - azimuth and angle of incidence of bedding in Paleozoic sediments according to oriented core data 
Геологические факторы оценки критериев перспектив нефтегазоносности по данным бурения и испытания скважин

Геологические факторы базируются на особенностях геологического строения и флюидонасыщении КЗ ДЮК. Раскарстованные, интенсивно кавернозные и трещинные коллекторные зоны в карбонатных породах, связанные с древними зонами гипергенеза, выделяются как в зоне контакта пород фундамента и осадочного чехла, так и в «глубинном» палеозое. При их вскрытии наблюдается резкое увеличение скорости проходки, провалы бурового инструмента и поглощение бурового раствора, которое иногда принимает катастрофический характер (более 5-10 м $3 /$ ч).

Вскрытие высокоемкой К3, сопровождающееся катастрофическим поглощением бурового раствора, при ранее принятой технологии бурения на глинистом растворе с удельным весом от 1,14 до 1,2 г/см ${ }^{3}$ и конструкции скважин с кондуктором, башмак которого находился на глубине от 300 м, максимум до 600 м, как правило, приводило к аварийной ситуации и в конечном итоге к ликвидации скважины в результате геологического осложнения.

Связывая поглощения с процессом промывки скважины глинистым раствором под давлением бурового насоса в образованиях палеозойского фундамента, необходимо отметить, что оно (поглощение) возможно при наличии в К3 сжимаемого флюида (нефть, газ), удельный вес которого в пластовых условиях

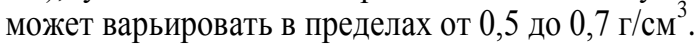

В ряде литературных источников [19, 20] поглощения, а тем более катастрофические поглощения, в породах фундамента объясняют наличием залежей углеводородов. Катастрофические поглощения с последующей ликвидацией скважин в отложениях глубинного палеозоя и пластах М и М1 отмечались на Северо-Калиновой (скв. 26, 29), Кильсинской (скв. $380)$, Урманской (скв. 3), Амурской (скв. 1), Рогозинской (скв. 8) и ряде других площадей.

В то же время анализ бурения показывает, что при вскрытии высокопроницаемой КЗ ДЮК насыщенной пластовой водой с минерализацией $60-80$ г/л и удельным весом 1,05-1,08 г/см поглощений не происходит, скважина успешно бурится до проектного забоя, а при испытании КЗ в открытом стволе (или в колонне) получают значительные притоки пластовой воды. Так, в скважине 44 Солоновской площади из интервала перфорации 3136-3145 м дебит пластовой воды на динамическом уровне 550 м составил $432 \mathrm{~m}^{3} /$ сут при газовом факторе $1,38 \mathrm{~m}^{3} / \mathrm{m}^{3}$.

Неопределенная ситуация возникает в тех случаях, когда скважина вскрывает КЗ с первоначально выраженным поглощением бурового раствора, которое затем (иногда при дальнейшем углублении, иногда даже без него) переходит в поступление пластовой воды вплоть до интенсивного вытеснения бурового раствора из скважины.

На практике такие примеры не редки - скважина Ураловская 302, интервал 2883-2889 м, где после интенсивного поглощения начался процесс поступления из поглощающей ранее зоны пластовой воды, скважина Рагозинская ПО-3, в которой также после вскры- тия поглощающего интервала 2583,9-2587,8, при его дальнейшей проработке, поглощение сменилось на интенсивный водоприток из этого же интервала.

Учитывая влияние трещиновато-кавернознокарстовых прослоев в составе продуктивной КЗ ДЮК на процесс бурения и испытания скважины, необходимо рассмотреть возможные сценарии распределения флюидных разделов в скважинах, расположенных в нефтяной, водо-нефтяной и законтурной зонах залежи УВ (рис. 2, А).

Сиенарий первый. Бурение скважины в водоносной части пласта в непосредственной близости от контура залежи УВ при поглощении сопровождается обширным проникновением бурового раствора в трещиннокавернозно-карстовую зону коллектора (рис. 2, Б), что обеспечивается сжатием углеводородного флюида (газ, нефть). Пластовая вода при этом, выполняя роль несжимаемого буфера, занимает положение между буровым раствором и залежью углеводородов.

При испытании скважины фильтрат глинистого раствора, имея повышенную вязкость относительно пластовой воды и нефти, вытесняется преимущественно из трещин и лишь частично из поровокавернозно-карстовых зон. Дальнейшее расширение газонефтяной зоны воздействует на пластовую воду буфера, способствуя её переливу и фонтанированию на устье скважины (рис. 2, Б-1).

Притоки пластовой воды на «переливе» - достаточно распространенное явление при освоении КЗ в ДЮК. Небольшое превышение пластового давления над гидростатическим (5-10 атм) в отложениях фундамента юго-восточной части ЗСП, при глубинах залегания его кровли 2600-3100 м, с учётом повышенного удельного веса высокоминерализованной пластовой воды $\left(1,05-1,08\right.$ г/см $\left.{ }^{3}\right)$, не может служить основанием для наблюдаемых притоков, достигающих на переливе значений 100-200 м 3 суут и более. При этом поступающая пластовая вода зачастую характеризуется повышенным газовым фактором (2-8 $\left.\mathrm{m}^{3} / \mathrm{m}^{3}\right)$ относительно предельного газонасыщения $\left(1,6 \mathrm{~m}^{3} / \mathrm{m}^{3}\right)$ для вод палеозоя [21], что также косвенно свидетельствует о близости залежи углеводородов.

В качестве примера можно привести результаты испытания серых трещиноватых кавернозных известняков в интервале 3092-3013 м скважины Р-13 Нижнетабаганской площади, где после перфорации и вызова притока сменой глинистого раствора на воду в течении двух часов наблюдался перелив технической воды дебитом 360-100 м³/ сут. Затем скважина в течении трёх часов переливала пластовой водой дебитом 70-80 м³ сут. Минерализация пластовой воды составляла 56 г/л, газовый фактор $-2,5 \mathrm{~m}^{3} / \mathrm{m}^{3}$, пластовое давление на глубине 3098 м - 318 атм.

Сиенарий второй (разновидность первого). Скважина пробурена в водонефтяной зоне залежи со значительным интервалом вскрытия водоносной части (рис. 2, В). В процессе поглощения и снижения объёма углеводородного флюида пластовая вода в интервале скважины вытесняется буровым раствором в подошвенную часть участка нефтяной залежи, выполняя роль несжимаемого буфера между буровым раствором и залежью УВ. 

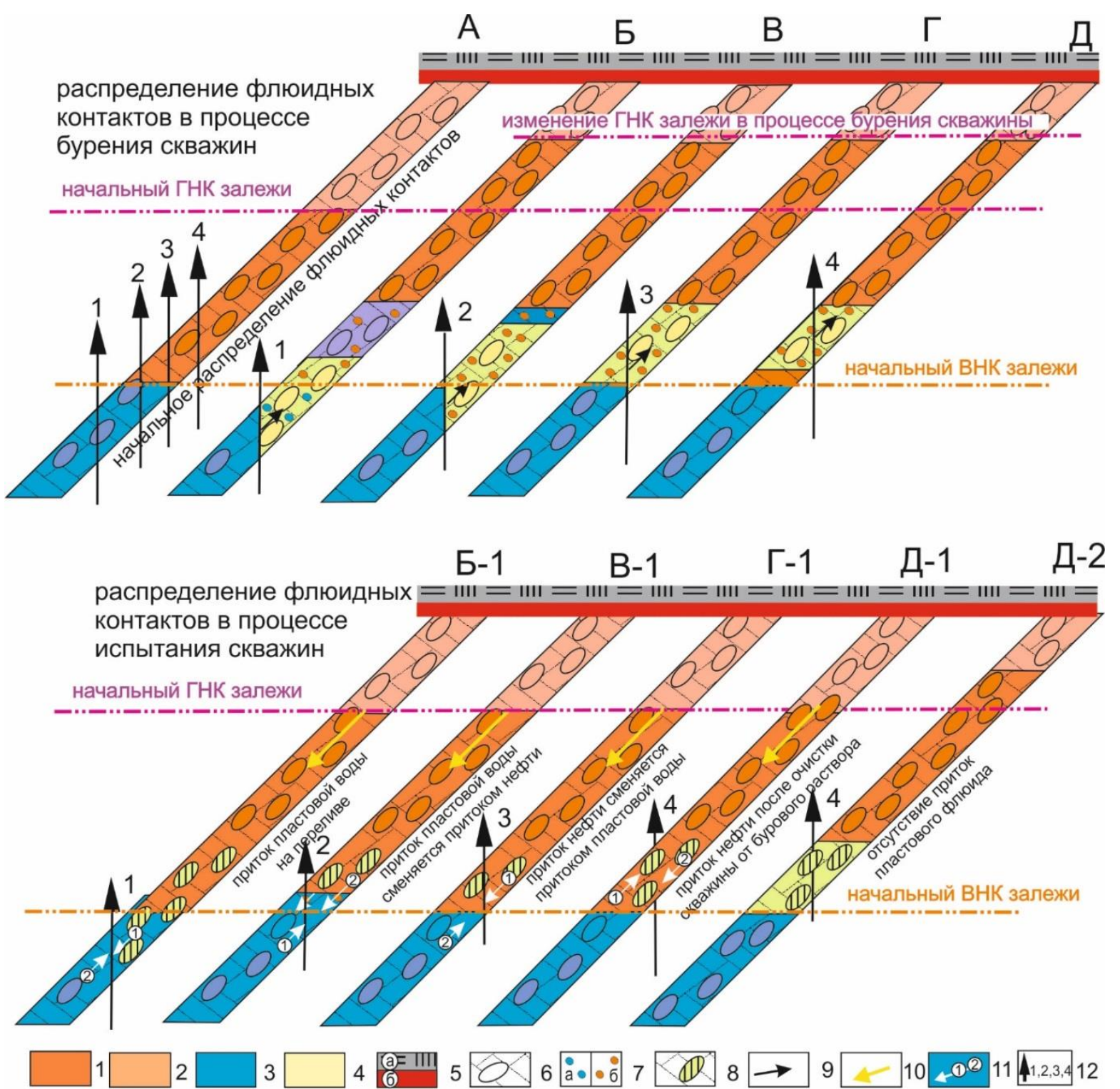

Рис. 2. Особенности распределения флюидных контактов в трещинно-кавернозно-карстовом коллекторе фундамента при бурении и испытании скважин, расположенных в различных частях залежи углеводородов: 1 - нефтенасыщенная, 2 - газонасыщенная, 3 - водонасыщенная зона коллектора; 4 - буровой раствор; 5 - стратиграфическое несогласие (кровля фундамента) или тектонические нарушения складчатости; 7 - трещиино-кавернозная КЗ; 8 - остаточные флюиды воды (а) и нефти (б); 8 -локализачия остаточного бурового раствора в трещинно-кавернозном коллекторе при испытании скважины; 9 - направление движение бурового раствора в процессе бурения, обусловленное «сжатием» газа и газонасыщенного флюида (нефти); 10 - направление растирения залежи углеводородов в процессе испытания скважины; 11- скважина вскрывает законтурную зону залежи нефти (1), зону водо-нефтяного контакта (2-3), залежь нефти (4)

Fig. 2. Peculiarities of fluid contacts distribution in the fractured-cavernous-karst basement reservoir during drilling and testing wells located in different parts of the hydrocarbon deposit: 1 - oil-bearing, 2 - gas-bearing, 3 - waterbearing zones of reservoir; 4 - drilling liquid; 5 - stratigraphic unconformity basement top (a) or tectonic squaring disturbances (b); 6 - fractured-cavernous reservoir zone (RZ); 7 - residual fluids of water (a) and oil (b); 8 -localization of residual drilling mud in a fractured-cavernous reservoir when well testing; 9 - movement direction of drilling fluid during drilling, due to the «compression» of gas and gas-saturated fluid (oil); 10 - expansion direction of hydrocarbon deposits during well testing; 11 -test flow sequence; 12 - well penetrates the peripheral zone of the oil reservoir (1), the zone of water-oil contact (2-3), the oil reservoir (4)

При испытании в процессе расширения объёмов углеводородного флюида в начальный момент после очистки скважина работает самоизливом пластовой воды или пластовой воды с плёнкой нефти, а затем в процессе дальнейшего дренирования объекта происходит замена пластовой воды на нефть, причем доля нефти может достигать 100 \%, т. е. происходит практически полная замена первоначально полученного флюида (рис. 2, В-1).

Примером может служить ситуация на скважине Северо-Останинская Р-5, где при испытании в карбонатном разрезе объекта в интервале 2827-2834 м в 
процессе возбуждения пласта сменой глинистого раствора на техническую воду и снижения динамического уровня, скважина начала переливать сначала технической водой, а затем пластовой водой дебитом $100 \mathrm{~m}^{3} /$ сут с незначительной пленкой нефти. В течение 11 суток наблюдения за переливом пластовая вода постепенно сменилась на нефть, и скважина вышла на фонтанирование газонефтяной смесью $\mathrm{QH}=84 \mathrm{~m}^{3} / \mathrm{cyт}$, QГ $=195$ тыс. м $^{3} /$ сут без признаков пластовой воды.

В качестве аналогий можно привести результаты испытаний по скважине Останинская 438 (интервал 2750-2755 м), где после её возбуждения скважина, сначала работая пластовой водой и нефтью, в процессе очистки полностью перешла на нефть. В скважине Герасимовская 301 при испытании интервала 2779-2791 м первоначально наблюдался перелив пластовой воды с газом и пленкой нефти, который при дальнейшей очистке в течение пяти суток полностью сменился на фонтанный приток нефти.

Сценарий третий. Скважина пробурена в водонефтяной зоне с незначительным интервалом вскрытия водоносной части. Буровой раствор в результате сжатия углеводородного флюида занимает объёмы трещинно-кавернозно-карстового пространства, разделяя нефтяную и водоносную части залежи (рис. 2, Г).

При испытании скважины, после её очистки, отмечается приток безводной нефти, сменяющийся затем притоком пластовой воды (рис. 2, Г-1). Вероятно, это обусловлено тем, что остаточные объёмы не вытесненного бурового раствора в нефтяной зоне коллектора способствуют дополнительному продвижению в околоскважинном пространстве нефтяной залежи, затронутой процессами бурения и испытания, в водоносную часть. В результате этого на начальном этапе испытания скважина, работающая нефтью, затем переходит на пластовую воду за счёт формирования конуса обводнения законтурной области.

В качестве примера можно привести результаты испытания скважины 4 Верхне-Тарского месторождения, где первоначальный приток нефти дебитом $120 \mathrm{~m}^{3} /$ сут. за несколько дней фонтанирования полностью заместился пластовой водой.

Сценарий четвёртый. Бурение скважины в нефтяной зоне продуктивного пласта при поглощении сопровождающегося обширным проникновением бурового раствора в трещинно-кавернозную зону коллектора, что обеспечивается сжатием пластового флюида (газ, нефть) в гипсометрически повышенной части залежи (рис. 2, Д).

При испытании интервала поглощения в колонне снижение забойного давления инициирует расширение ранее сжатого флюида, в результате чего происходит очищение прежде всего трещинной, а затем частично и кавернозно-карстовой зон коллектора от глинистого раствора, и скважина переходит на фонтанирование нефтью (рис. 2, Д-1).

Примером рассматриваемого сценария может служить скв. 42 Арчинской площади, где в процессе бурения интервала глубин 3053-3061 м наблюдался провал инструмента и нефтепроявления в глинистом растворе. Дальнейшее бурение сопровождалось по- стоянным поглощением промывочной жидкости, которое, тем не менее, не приобретало катастрофический характер, поэтому блокирующие добавки в раствор не вводились, что позволило сохранить гидродинамическую связь КЗ и скважины. При испытании интервала 3050-3060 м в течение месяца (31 день) проводилась очистка скважины от раствора и шлама, после чего был получен фонтан нефти дебитом $84,6 \mathrm{~m}^{3} /$ сут на штуцере 5 мм.

Пятый сценарий. В случае аварийной ситуации, связанной с поглощением, что требовало длительных работ по его устранению, предусматривалась закачка значительных объёмов блокирующих наполнителей, а иногда и тампонажной смеси на основе цементного раствора (рис. 2, Д-2). Проведение этих мероприятий сопровождается потерей фильтрационно-емкостных свойств КЗ. В результате при испытании, как правило, приток флюида или отсутствует, или в случае низкого качества цементажа скважины получают пластовую воду как следствие заколонных перетоков из других водонасыщенных объектов.

Примером отсутствия притока из интервала, который при бурении проявлял себя как катастрофически поглощающий, может служить скважина Р-4 Тамбаевской площади, где при проводке открытого ствола наблюдались многочисленные нефтепроявления и поглощения промывочной жидкости (интервалы 3229-3260, 3304-3308, 3507-3555, 3589-3601 м), а цементирование обсадной колонны имеет признаки низкого качества. В итоге из интервалов испытания получены либо слабые притоки пластовой воды или фильтрата бурового раствора, либо отсутствие какого-либо притока.

Пример получения практически одинаковых результатов - испытание двух объектов на скв. 31 Калганакской площади, один из которых в интервале 2748-2760 м водонасыщен, а второй в интервале 2721-2730 м, при вскрытии которого наблюдался провал бурового инструмента и резкое увеличение скорости проходки, сопровождаемое катастрофическим поглощением, вероятно нефтегазонасыщен. В результате по обоим объектам получен переливающий приток пластовой воды, без признаков выхода поглощенного раствора (с большим количеством блокирующих поглощение наполнителей). Качество цементирования обсадной колонны в интервале ДЮК низкое, поэтому все результаты испытания относятся к нижнему объекту. Верхний поглощающий объект блокирован во время бурения, и возможно цементирование обсадной колонны.

\section{Технологические факторы оценки критериев перспектив нефтегазоносности по данным бурения и испытания скважин}

Технологические факторы отражают проблему качества цементирования (изоляции) затрубного пространства, вносящую серьёзные искажения в результаты испытания объектов ДЮК и их эксплуатацию в колонне.

Большая часть обсадных колонн, спускаемых в перспективные разрезы ДЮК, содержащие КЗ, по ре- 
зультатам проверки характеризуется низким качеством цементирования. Последствия этого носят крайне негативный характер, ставящий под сомнение достоверность результатов испытаний. При анализе явно прослеживается тренд - чем вероятнее нахождение в обсаживаемом интервале высокоемкой КЗ, тем хуже качество цементирования обсадной колонны в перспективном интервале, вплоть до практически полного отсутствия цемента в затрубном пространстве. Объясняется это поглощением тампонажной цементной смеси коллекторной зоной. В случае спуска обсадной колонны в разрез ДЮК, не содержащий высокоёмкий коллектор, или при насыщении трещинно-кавернозно-карстовой зоны пластовой водой качество цементирования получается вполне приемлемым, поглощений тампонажной смеси и блокирования КЗ не происходит.

Рассматривая особенности испытания поглощающих объектов, необходимо отметить, что перед получением пластового флюида наблюдается процесс очистки пласта от поглощенного бурового раствора (при условии сохранения гидродинамической связи КЗ с скважиной).

В то же время по испытанию ряда скважин (приведенных выше по тексту) видно, что ранее поглощающий объект при бурении, по которому проводились противопоглощающие мероприятия (закачки разного рода блокираторов-наполнителей - резиновой и полипропиленовой крошки, древесных опилок, химреагентов-сгустителей, глинисто-цементных смесей и др.), в процессе испытания в колонне начинает работать пластовой водой и по результатам опробования признаётся водонасыщенным. Исследование акустической цементометрии в таких скважинах свидетельствуют о низком качестве изоляции затрубного пространства, что и предопределяет приток пластовой воды из водоносных коллекторов, расположенных ниже или выше зоны перфорации. Дополнительные изоляционные работы, проводимые в таких скважинах с целью ликвидации затрубного перетока, в очень редких случаях приводили к положительному результату.

Примером такой ситуации могут служить результаты испытаний объектов в параметрических глубоких скважинах П-2 Еллей-Игайская, П-3 Тамбаевская и других, где при отмечаемых признаках УВ насыщения и поглощениях бурового раствора различной интенсивности, наблюдаемых в процессе бурения на различных участках карбонатного палеозойского разреза, при испытании в колонне получены фонтанные притоки пластовой, часто сильно разгазированной воды с пленками нефти и конденсата.

Качество затрубной изоляции на этих скважинах по результатам инструментальных замеров акустической цементометрии (АКЦ) признано неудовлетворительным. Дополнительные цементажи с целью изоляции объектов были выполнены без видимых успехов.

Блоковая слоисто-складчатая модель строения палеозойских образований отражается в резкой латеральной неоднородности продуктивных резервуаров как в разрезе, так и по площади. Роль блоковой тектоники и слоистой складчатости в распределении нефте- газоносности можно проследить на примере бурения скважин 137 и 133 Южно-Табаганской площади.

В соответствии со стратиграфическими определениями возраста, породы кровли фундамента в скважине 137 в диапазоне глубин 3005-3052 м представлены доломитизированными, кавернозно-трещиноватым органогенным известняками верхнедевонского возраста, из которого в интервалах 3028-3032 м (абс. отм. 2892-2896 м) и 3046-3051 м (абс. отм. - 2910-2915 м) при испытании в колонне притоки нефти на 14 мм штуцере соответственно составили 412 и $318 \mathrm{~m}^{3} /$ сут. Из нижележащих тёмно-серых глинистых известняков аналогичного возраста при испытании интервала 3964-3073 м (абс. отм. -2927-2938 м) на динамическом уровне 1167 м получена плёнка нефти.

В скважине 133, расположенной в 200 м западнее скв. 137 в диапазоне глубин 3057-3104 м (абс. отм. 921-2926 м) кровля палеозоя охарактеризована тёмно-серым трещиноватым мергелем нижнего девона без признаков нефтегазоносности. Ввиду отсутствия нефтеперспективных объектов скважина была ликвидирована без опробования.

Возрастные и литологические различия пород фундамента рассматриваемых скважин обусловлены наличием тектонического нарушения и литологической слоисто-складчатой неоднородностью, влияющими на пространственную локализацию залежи углеводородов.

Рассматривая результаты бурения и испытания палеозойских разрезов скважин, документация которых формировалась на бумажных носителях (дела скважины), с позиции переоценки перспектив их нефтегазоносности, следует отметить, что при их оцифровке и в дальнейшем при проводимом анализе, как правило, не использовались и не учитывались в полном объеме как ежедневные сводки бурения скважины, так и другая архивная информация (ежемесячные информационные сводки по бурению НГРЭ, ежегодные обобщающие геологические отчеты НГРЭ). Этот факт затрудняет отслеживание случаев поглощения бурового раствора в процессе проводки скважины за исключением серьезных аварийных ситуаций, отраженных в цифровом деле скважины. Поэтому анализ бурения скважины необходимо проводить с использованием всего набора архивных первоисточников.

\section{Выводы}

1. На базе блоковой слоисто-складчатой модели строения пород фундамента спрогнозировано поведение и распределение флюидных контактов залежи УВ при бурении и испытании трещиннокавернозно-карстовых КЗ в ДЮК.

2. С учётом анализа результатов бурения и испытания высокопродуктивных коллекторных зон фундамента по «архивным» данным пробуренных скважин (дела скважин, отчеты НГРЭ и ТТГУ, информационные сводки) установлены критерии прогноза нефтегазоносности, позволяющие определить возвратные объекты для продолжения нефтепоисковых работ на ранее изученных струк- 
турах и площадях, выведенных из бурения с отрицательным результатом.

3. На конкретных примерах показана значимость аналитического исследования исторических данных бурения «архивных» скважин, вскрывших потенциально-продуктивные КЗ в ДЮК, но не завершённых получением положительного результата, исходя из особенностей поведения продуктивных УВ-залежей и их флюидных контактов, при бурении и испытании трещинно-кавернознокарстовых зон блоково-складчатой модели ДЮК.

\section{СПИСОК ЛИТЕРАТУРЫ}

1. Paleozoic of West Siberia - geological structure, oil and gas bearing, seismogeological models of oil and gas fields / V. Kontorovich, L. Kalinina, A. Kalinin, M. Soloviev // Conference Proceedings Geomodel. - Venue, September 2018. V. 2018. - P. 1-5

2. Kontorovich V.A. Petroleum potential of reservoirs at the Paleozoic-Mesozoic boundary in West Siberia: seismogeological criteria (example of the Chuzik-Chizhapka regional oil-gas accumulation) // Russian Geology and Geophysics. - May 2007. V. 48. - № 5. - P. 422-428.

3. Paleozoic facies megazones in the basement of the West Siberian geosyncline / E.A. Yolkin, A.E. Kontorovich, N.K. Bakharev, S.Yu. Belyaev, A.I. Varlamov, N.G. Izokh, A.V. Kanygin, V.A. Kashtanov, N.P. Kirda , A.G. Klets, V.A. Kontorovich, V.I. Krasnov, V.A. Krinin, S.A. Moiseev, O.T. Obut, S.V. Saraev, N.V. Sennikov, V.M. Tishchenko // Russian Geology and Geophysics. - June 2007. - V. 48. - № 6. - P. 491-504.

4. Geological structure of the basement of western and eastern parts of the West-Siberian / K. Ivanov, V. Erokhin, V. Ponomarev, O. Pogromskaya, S. Berzin // International journal of environmental \& science education. - May 2016. - V. 11. - № 14. - P. 6409-6432.

5. Сейсмогеологические модели палеозойских комплексов и нефтегазоперспективных объектов юго-востока Западной Сибири (Новосибирская область) / В.А. Конторович, Л.М. Калинина, А.Ю. Калинин, К.И. Канакова, М.В. Соловьев // Технологии сейсморазведки. - 2017. - № 3. - С. 85-95.

6. Конторович В.А., Калинина Л.М. Геологическое строение и нефтегазоносность палеозоя Западной Сибири, модели эталонных месторождений // Бурение и нефть. -2019. - № 11. C. $40-47$.

7. Ковешников А.Е. Резервуары нефти и газа в доюрских образованиях Западно-Сибирской геосинеклизы // Известия Томского политехнического университета. Геология нефти и га3а. - 2011. - T. 319. - № 1. - С. 147-151.

8. Запивалов Н.П. Метасоматическая доломитизация и нефтегазоносность карбонатных пород (наноэффекты образования вторичных высокопродуктивных коллекторов) // Наука и технологические разработки. - 2009. - Вып. 2. - Т. 88. - С. 32-39.

9. Геологическое изучение и нефтегазоносность палеозойских отложений Западной Сибири / А.В. Ступакова, А.В. Соколов, Е.В. Соболева, Т.А. Кирюхина, И.А. Курасов, Е.В. Бордюг // Георесурc. -2015 . - № 2 (61). - C. 63-76.

10. The characteristics and origins of thief zones in the Cretaceous limestone reservoirs of Central and southern Mesopotamian Basin / Hangyu Liu, Kaibo Sh, Bo Liu, Xinmin Song, Liben Deng, Rui Guo, Zhongyuan Tian, Yong Li, Ya Deng, Genjiu Wang // Journal of Petroleum Science and Engineering. - June 2021. - V. 201. 108395 .
4. Выделение в разрезах скважин объектов, с высокой степенью вероятности их нефтегазоносности, по данным бурения и испытания скважин может стать весомым основанием для бурения современных технологичных скважин-дублеров и открытия «пропущенных» в свое время залежей УВ, а также послужить полигоном для апробирования новых полевых и интерпретационных методик сейсморазведочных, грави-магниторазведочных, геохимических и других видов ГРР.

11. Effects of vugs on resistivity of vuggy carbonate reservoirs / H.E. Jiahuan, Min Li, Keming Zhou, Yu Yang, Bing Xie, Nong Li, Lurui Dang, Yanbing Tang // Petroleum Exploration and Development. - June 2020 - V. 47. - № 3. - P. 527-535.

12. Ehrenberg S.N., Baek H. Deposition, diagenesis and reservoir quality of an Oligocene reefal-margin limestone succession: Asmari Formation, United Arab Emirates // Sedimentary Geology. - December 2019. - V. 393. - 105535 p.

13. Poon X., Ramkumar M., Nagarajan M., Mathew J. Episodic dolomitization of Paleozoic limestones in the Kinta Valley, Malaysia: implications on porosity evolution and reservoir properties // Energy Geoscience. - October 2021. - V. 2. - № 4. P. 298-307.

14. Valencia F.L., Laya J.C. Deep-burial dissolution in an OligoceneMiocene giant carbonate reservoir (Perla Limestone), Gulf of Venezuela Basin: implications on microporosity development // Marine and Petroleum Geology. - March 2020. - V. 113. $104144 \mathrm{p}$.

15. Main controlling factors and distribution of high-quality deep dolomite reservoirs in typical cratonic basins in China / Z. Jianyong, N. Xinfeng, W. Xingning, L. Wenzheng, H. Yi, C. Yanna, L. Xueju, G. Mingfeng, T. Han, Z. Mao // Journal of Natural Gas Geoscience. - April 2018. - V. 3. - № 2. - P. 81-93.

16. Новые подходы к изучению нефтегазового потенциала доюрских отложений Западно-Сибирской нефтегазовой провинции / В.В. Хараханов, Н.М. Кулишкин, С.И. Шлёнкин, А.В. Олюнин // Геология нефти и газа. - 2015. - № 6. - С. 63-77.

17. Ежова А.В., Меркулов В.П., Чеканцев В.А. Геологическая модель строения палеозойского фундамента СевероОстанинского нефтяного месторождения (Томская область // Горный журнал. - 2012. - № 4. - С. 35-39.

18. Макаренко С.Н., Савина Н.И. Новые материалы по стратиграфии девона центральной части Нюрольской впадины // Региональная стратиграфия позднего докембрия и палеозоя Сибири: сборник научных трудов. - Новосибирск, 2013. C. $124-132$

19. Способ поиска залежей нефти в породах фундамента: пат. Рос. Федерация № 2507547, заявл. 14.0.2011; опубл. 20.09.2012. Бюл. № 26.

20. Терентьев С.Э., Богданов Б.П. Особенности определения насыщения зон поглощения промывочной жидкости в карбонатных постройках Тимано-Печёрской провинции // Нефтегазовое дело. - 2013. - № 2. - С. 123-148.

21. Новиков Д.А. Характеристика равновесий в системе вода-газ на примере палеозойских отложений юго-восточных районов Западной Сибири // Интерэкспо Гео-Сибирь. - 2008. - № 5. C. $84-89$.

Поступила: 29.12.2021 г.

\section{Инсормация об авторах}

Белозёров В.Б., доктор геолого-минералогических, заведующий лабораторией геологии, Национальный исследовательский Томский политехнический университет.

Силкин $\boldsymbol{\Gamma . E . , ~ д и р е к т о р ~ Ф и л и а л а ~ О О О ~ « Г е о П р а и ̆ м » - « Т о м с к а я ~ г е о ф и з и ч е с к а я ~ к о м п а н и я » . ~}$ 
UDC 550.53

\title{
CRITERIA FOR REASSESSMENT OF OIL AND GAS POTENTIAL OF RESERVOIR ZONES IN SOUTHEASTERN WESTERN SIBERIA BASEMENT
}

\author{
Vladimir B. Belozerov1, \\ BelozerovVB@hw.tpu.ru \\ Gennady E. Silkin², \\ gsilkin@geoprime.ru
1 National Research Tomsk Polytechnic University, 30, Lenin avenue, Tomsk, 634050, Russia. 39, Frunze avenue, Tomsk, 634029, Russia. \\ 2 Branch of GeoPrime LLC - Tomsk Geophysical Company,
}

\begin{abstract}
Relevance. The Paleozoic formations of Western Siberia are the main object of hydrocarbon potential further increase of the considered territory. The geological structure complexity of the basement rocks, the unsatisfactory quality of drilling, casing and testing of wells caused low efficiency of oil prospecting in the Paleozoic sediments, where all the identified hydrocarbon deposits and accumulations were discovered concurrently with the exploration of the sedimentary cover objects. One of the promising directions for increasing the prospecting efficiency in basement rocks is related to the analysis of drilling features and test results of previously drilled wells, where we can distinguish the geological and technological factors. The geological factor considers the results of drilling and well testing from the position of a block, folded, layered model of the structure of a fractured-porous-cavernous reservoir zone allocated as part of the Paleozoic complex. The analyzed model evaluates the changing possibility of the compressible fluid (oil, gas) volume during drilling and well testing. During drilling, as a result of increased pressure at the bottomhole relative to the reservoir pressure in a productive formation with abnormally high reservoir properties, there is a decrease in the volume of hydrocarbon fluid, which leads to the absorption of drilling fluid, sometimes to a complete loss of circulation. This effect can be observed when drilling a well both in the contour of the reservoir and in the aquifer in the immediate vicinity of it. When well testing and decreasing pressure during its development, the expansion (relaxation) of previously compressed volumes of hydrocarbon fluid occurs. In the case of drilling a well in the water-oil zone, alternating water-oil and oil-water inflows are observed, and if the well is located in the water-bearing part of the reservoir, the spontaneous outflow or high flow rates at low dynamic levels of highly mineralized formation water with increased values of the gas factor relative to the limit saturation values are noted. The technological factor assesses the quality of the production casing cementing, which affects the final test results and, as a consequence, the assessment of the oil and gas potential of the analyzed well section. The systematization of the drilling and testing results allows us to determine the criteria for assessing the oil and gas potential of the studied wells and areas, in order to resume prospecting for the discovery of hydrocarbon deposits in the rocks of the pre-Jurassic complex.

The purpose of the research is to analyze the results of drilling and testing wells carried out in the basement rocks of the southeastern part of the West-Siberian Plate in order to identify oil-promising areas and resume prospecting operations in previously studied areas.

The object of the study is the Paleozoic basement sediments of the southeastern part of the West Siberian Plate, which are represented by rocks of different material composition, including carbonate varieties.

The authors have carried out the analysis of the results of drilling and testing wells in the Paleozoic complex, and determined the criteria of the obtained data for the possible resumption of oil prospecting in areas previously studied by deep drilling.
\end{abstract}

Key words:

Pre-Jurassic sedimentary complex, basement rocks, Pre-Jurassic sedimentary complex test results, drilling fluid absorption, formation water overflows.

\section{REFERENCES}

1. Kontorovich V., Kalinina L., Kalinin A., Soloviev M. Paleozoic of West Siberia - geological structure, oil and gas bearing, seismogeological models of oil and gas fields. Conference Proceedings Geomodel. Venue, September 2018. Vol. 2018, pp. 1-5.

2. Kontorovich V.A. Petroleum potential of reservoirs at the Paleozoic-Mesozoic boundary in West Siberia: seismogeological criteria (example of the Chuzik-Chizhapka regional oil-gas accumulation). Russian Geology and Geophysics, May 2007, vol. 48, no. 5, pp. 422-428.

3. Yolkin E.A., Kontorovich A.E., Bakharev N.K., Belyaev S.Yu., Varlamov A.I., Izokh N.G., Kanygin A.V., Kashtanov V.A., Kirda N.P., Klets A.G., Kontorovich V.A., Krasnov V.I., Krinin V.A., Moiseev S.A., Obut O.T., Saraev S.V., Sennikov N.V., Tishchenko V.M. Paleozoic facies megazones in the basement of the West Siberian geosyncline. Russian Geology and Geophysics, June 2007, vol. 48, no. 6, pp. 491-504.

4. Ivanov K., Erokhin V., Ponomarev V., Pogromskaya O., Berzin S Geological structure of the basement of western and eastern parts of the West-Siberian. International journal of environmental \& science education, May 2016, vol. 11, no. 14, pp. 6409-6432.
5. Kontorovich V.A., Kalinina L.M., Kalinin A.Yu., Kanakova K.I., Solovev M.V. Seismogeological models of Paleozoic complexes and oil and gas prospective objects in the South-East of Western Siberia (Novosibirsk region). Seismic exploration technologies, 2017, no. 3, pp. 85-95. In Rus.

6. Kontorovich V.A., Kalinina L.M. Geological structure and oil and gas potential of the Paleozoic of Western Siberia, models of reference deposits. Drilling and oil, 2019, no. 11, pp. 40-47. In Rus.

7. Koveshnikov A.E. Oil and gas reservoirs in the Pre-Jurassic formations of the West Siberian geosyneclise. Bulletin of the Tomsk Polytechnic University, 2011, vol. 319, no. 1, pp. 147-151. In Rus.

8. Zapivalov N.P. Metasomatic dolomitization and oil and gas content of carbonate rocks (nanoeffects of formation of secondary highly productive reservoirs. Science and technological developments, 2009, vol. 2, pp. 32-39. In Rus.

9. Stupakova A.V., Sokolov A.V., Soboleva E.V., Kiryuhina T.A., Kurasov I.A., Bordyug E.V. Geological study and oil and gas potential of Paleozoic deposits of Western Siberia. Geo resource, 2015, no. 2 (61), pp. 63-76. In Rus.

10. Hangyu Liu, Kaibo Sh, Bo Liu, Xinmin Song, Liben Deng, Rui Guo, Zhongyuan Tian, Yong Li, Ya Deng, Genjiu Wang. The 
characteristics and origins of thief zones in the Cretaceous limestone reservoirs of Central and southern Mesopotamian Basin. Journal of Petroleum Science and Engineering, June 2021, vol. 201, $108395 \mathrm{p}$

11. Jiahuan H.E., Min Li, Keming Zhou, Yu Yang, Bing Xie, Nong Li, Lurui Dang, Yanbing Tang. Effects of vugs on resistivity of vuggy carbonate reservoirs. Petroleum Exploration and Development, June 2020, vol. 47, no. 3, pp. 527-535.

12. Ehrenberg S.N., Baek H. Deposition, diagenesis and reservoir quality of an Oligocene reefal-margin limestone succession: Asmari Formation, United Arab Emirates. Sedimentary Geology, December 2019, vol. 393, $105535 \mathrm{p}$.

13. Poon X., Ramkumar M., Nagarajan M., Mathew J. Episodic dolomitization of Paleozoic limestones in the Kinta Valley, Malaysia: implications on porosity evolution and reservoir properties. Energy Geoscience, October 2021, vol. 2, no. 4, pp. 298-307.

14. Valencia F.L., Laya J.C. Deep-burial dissolution in an OligoceneMiocene giant carbonate reservoir (Perla Limestone), Gulf of Venezuela Basin: implications on microporosity development. Marine and Petroleum Geology, March 2020, vol. 113, 104144 p.

15. Jianyong Z., Xinfeng N., Xingning W., Wenzheng L., Yi H., Yanna C., Xueju L., Mingfeng G., Han T., Mao Z. Main controlling factors and distribution of high-quality deep dolomite reservoirs in typical cratonic basins in China. Journal of Natural Gas Geoscience, April 2018, vol. 3, no. 2, pp. 81-93.

16. Harahanov V.V., Kulishkin N.M., Shlenkin S.I., Olyunin A.V. New approaches to the study of the oil and gas potential of the
Pre-Jurassic deposits of the West Siberian Oil and gas Province. Geology of Oil and Gas, 2015, no. 6, pp. 63-77. In Rus.

17. Ezhova A.V., Merkulov V.P., Chekantsev V.A. Geological model of the structure of the Paleozoic basement of the SeveroOstaninsky oil field (Tomsk region). Mining Magazine, 2012, no. 4, pp. 35-39. In Rus.

18. Makarenko S.N., Savina N.I. Novye materialy po stratigrafii devona tsentralnoy chasti Nyurolskoy vpadiny [New materials on the Devonian stratigraphy of the central part of the Nyrol Depression]. Regionalnaya stratigrafiya pozdnego dokembriya i paleozoya Sibiri: sbornik nauchnih trudov [Regional stratigraphy of the Late Precambrian and Paleozoic of Siberia: collection of scientific papers]. Novosibirsk, 2013. pp. 124-132.

19. Sahipov D.M, Sahipov E.M. Sposob poiska zalezhey nefti v porodakh fundamenta [Method of searching for oil deposits in the foundation rocks]. Patent RF no. 2507547, 2012.

20. Terentev S.E., Bogdanov B.P. Features of determining the saturation of the absorption zones of the washing liquid in the carbonate buildings of the Timan-Pechersk province. Oil and gas business, 2013, no. 2, pp. 123-148. In Rus.

21. Novikov D.A. Characteristics of equilibria in the water-gas system on the example of Paleozoic sediments of the southeastern regions of Western Siberia. Interexpo Geo-Siberia, 2008, no. 5, pp. 84-89.

Received: 29 December 2021.

\section{Information about the authors}

Vladimir B. Belozerov, Dr. Sc., head of the Geology Laboratory, National Research Tomsk Polytechnic University. Gennady E. Silkin, director, Branch of GeoPrime LLC - Tomsk Geophysical Company. 